\title{
Pengembangan Video Pembelajaran Matematika Untuk Kelas Iv Sd
}

\author{
Ismailah \\ Bidang Studi Teknik Informatika, Universitas Indraprasta PGRI \\ Ismailah859@gmail.com
}

Abstract: Learning must be carried out in an interactive, innovative and fun way so that students do no feel bored when following the subject presented. This study aims to design a learning video on mathematics in grade IV on the subject of the least common multiple and the greatest common factor. This research was conducted in Tanah Tinggi 06 Petang Elementary School, Central Jakarta. The research methodology used research and development with the ADDIE model approach which contains five steps; a) Analysis, b) Design, c), Develop, d), Implement, e). Evaluate. Data collection using a questionnaire, there are three validators consisting of two experts and one teacher. The validation result of the learning video with a mean of 3 means that it is in good category and the learning video is suitable for use in larger groups.

Keywords: development, video, validation result

Abstrak: Pembelajaran harus diselengggaraan secara interaktif, inovatif dan menyenangkan agar siswa tidak merasa bosan saat mengikuti mata pelajaran yang disampaikan. Penelitian ini bertujuan merancang video pembelajaran pada mata pelajaran matematika kelas IV pokok bahasan kelipatan persekutuan terkecil dan faktor persekutuan terbesar. Penelitian ini dilaksanakan di sekolah Dasar Negeri Tanah Tinggi 06 Petang Jakarta Pusat. Metodelogi penelitian digunakan penelitian dan pengembangan dengan pendekatan model ADDIE yang berisi lima langkah; a) Analysis, b) Design, c), Develop, d), Implement, e). Evaluate. Pengumpulan data menggunakan angket, ada tiga validator terdiri dari dua ahli dan satu guru. Hasil validasi terhadap video pembelajaran dengan rerata 3 artinya berkategori baik dan video pembelajaran layak digunakan pada kelompok yang lebih besar.

Kata Kunci: Pengembangan, Video, Hasil Validasi

\section{PENDAHULUAN}

Seluruh dunia sedang menghadapi pandemi global yaitu corona virus nineteen atau yang singkat covid19. Indonesia salah satu negara yang berdampak virus corona. Dengan adanya pandemi tersebut sangat mempengaruhi segala bidang terutama bidang pendidikan, adanya perubahan sistem pendidikan nasional mulai dari jenjang pendidikan anak usia dini sampai kepada level pendidikan tinggi yang mengharuskan pembelajaran di rumah (home learning) menggunakan daring. Belajar dirumah berdampak kepada kebosanan bagi siswa dalam proses belajar. maka untuk mengatasi kebosanan itu perlu ada pembelajaan yang interaktif dan menyenangkan.

Inovasi pembelajaran dengan membuat video pembelajaran sangat diperlukan bagi siswa saat ini untuk dapat memotivasi semangat belajar secara mandiri dengan mendengarkan dan memperhatikan tayangan video yang disampaikan oleh guru. Pembelajaran yang bervariasi merupakan suatu tuntutan bagi guru untuk terus memperhatikan kondisi dan keadaan lingkungan siswa. Pembelajaran yang menyenangkan merupakan mendorong peserta didik untuk senang belajar dan terus menumbuhkan rasa tertantang bagi dirinya, sehingga dapat memotivasi diri, aktif dan kreatif serta bertanggung jawab pada kesepakatan yang dibuat bersama (Kepmendikbud).

Dengan video pembelajaran diyakini dapat menciptakan suasana yang nyaman dan menyenangkan bagi siswa di rumah. Video merupakan teknologi penangkapan, perekaman, pengolahan, dan penyimpanan, pemindahan dan perekonstruksian urutan gambar diam dengan menyajikan adeganadegan dalam gerak secara elektronik 
(Simarmata, 2020). Selanjutnya video merupakan teknologi pengiriman sinyal atau visualisasi elektronik dari suatu gambar yang bergerak (Tonni Limbong, 2020). video yang terintegrasi dengan gambar, teks, suara dan grafik dapat memikat ingatan siswa dalam proses pembelajaran. Video memiliki kemampuan untuk membuat para siswa terpesona ketika menyaksikan drama yang ditampilkan kehadapan mereka (Sharon E. Smaldino., 2011).

Mata pelajaran matematikan cenderung sulit bagi siswa yang tingkat pengetahuan yang rendah, apalagi terkait dengan pokok bahasan perhitungan kelipatan persekutuan terkecil (KPK) dan faktor persekutuan terbesar (FPB). Untuk itu perlu media pembelajaran bervariasi yang dikemas dalam bentuk semenarik mungkin agar siswa termotivasi mempelajarinya.

Hasil pengamatan penulis terhadap mata pelajaran matematika ini banyak siswa mengalami kendala terhadap materi yang disampaikan oleh guru kelas melalui daring, sehingga orang tua siswa mengirim banyak pertanyaan untuk meminta guru kelas menjelaskan kembali dan disertai contohcontoh. Maka dalam mengatasi ini peneliti mencoba memberikan masukan alternatif kepada guru kelas IV untuk dibuatkan video pembelajaran yang dikemas dalam bahasa yang mudah dimengerti, apabila masih sulit memahaminya maka siswa dapat memutar kembali video tersebut secara terus - menerus sampai benar-benar memahaminya.

Hasil penelitian relevan yang dilakukan oleh (Titin Suryansyah, 2016) dengan judul pengembangan video pembelajaran untuk meningkatkan motivasi dan hasil belajar kognitif siswa kelas IV SD. Hasil dari penelitian tersebut mengatakan bahwa produk yang dikembangkan terbukti efektif meningkatkan motivasi dan hasil belajar kognitif siswa kelas IV SD gugus Pacarejo. Selanjutnya penelitian oleh (Reza Rizki Ali Akbar, Pengembangan video pembelajaran matematika berbantuan media sosial instagram sebagai alternatif pembelajaran, 2018) dengan judul pengembangan video pembelajaran matematika berbantuan media sosial instagram sebagai alternatif pembelajaran. Berdasarkan hasil penelitian tersebut menyimpulkan bahwa media video pembelajaran matematika berbantuan instagram sebagai alternatif pembelajaran valid dan layak digunakan sebagai media pembelajaran matematika.

Penelitian yang dikembangkan oleh peneliti saat ini memiliki ciri khas baik dari sisi software yang digunakan dan video dikemas dalam bahasa sederhana, interaktif dan menyenangkan bagi siswa yang sedang belajar dirumah, penelitian yang dilakukan hanya uji kelayakan produk video pembelajaran tidak sampai kepada uji efektifitas.

Berdasarkan uraian diatas, peneliti merumuskan masalah adalah 1. Bagaimana mengembangkan video pembelajaran matematika pokok bahasan KPK dan FPB pada siswa kelas IV SDN, 2. Apakah video pembelajaran yang dikembangkan layak digunakan untuk siswa kelas IV.

\section{METODE}

Tujuan penelitian ini adalah untuk menciptakan video pembelajaran yang interaktif dan menyenangkan bagi siswa, sehingga siswa dapat belajar secara mandiri dirumah serta agar siswa termotivasi untuk terus belajar.

Adapun tempat dan jadwal penelitian ini di Sekolah Dasar Negeri Tanah tinggi 06 petang jakarta pusat mulai awal ajaran baru tahun 2020.

Metode penelitian dengan menggunakan research and development (R\&D). Penelitian dan pengembangan adalah metode penelitian yang digunakan untuk menghasilkan produk tertentu dan menguji kefektifan produk tersebut menurut (Sugiyono, 2012). Selanjutnya Bord \& Gall dalam (Setyosari, 2010) mengatakan bahwa penelitian dan pengembangan adalah suatu proses untuk mengembangkan dan menvalidasi produk produk pendidikan. Penelitian ini menggunakan Pendekatan model ADDIE (Robert Maribe Branch., 2015) yang terdiri dari 5 langkah yaitu analyze, Design, developmen, implement and evaluate 
Rancangan flowchart pengembangan video pembelajaran menggunakan model ADDIE adalah sebagai berikut:

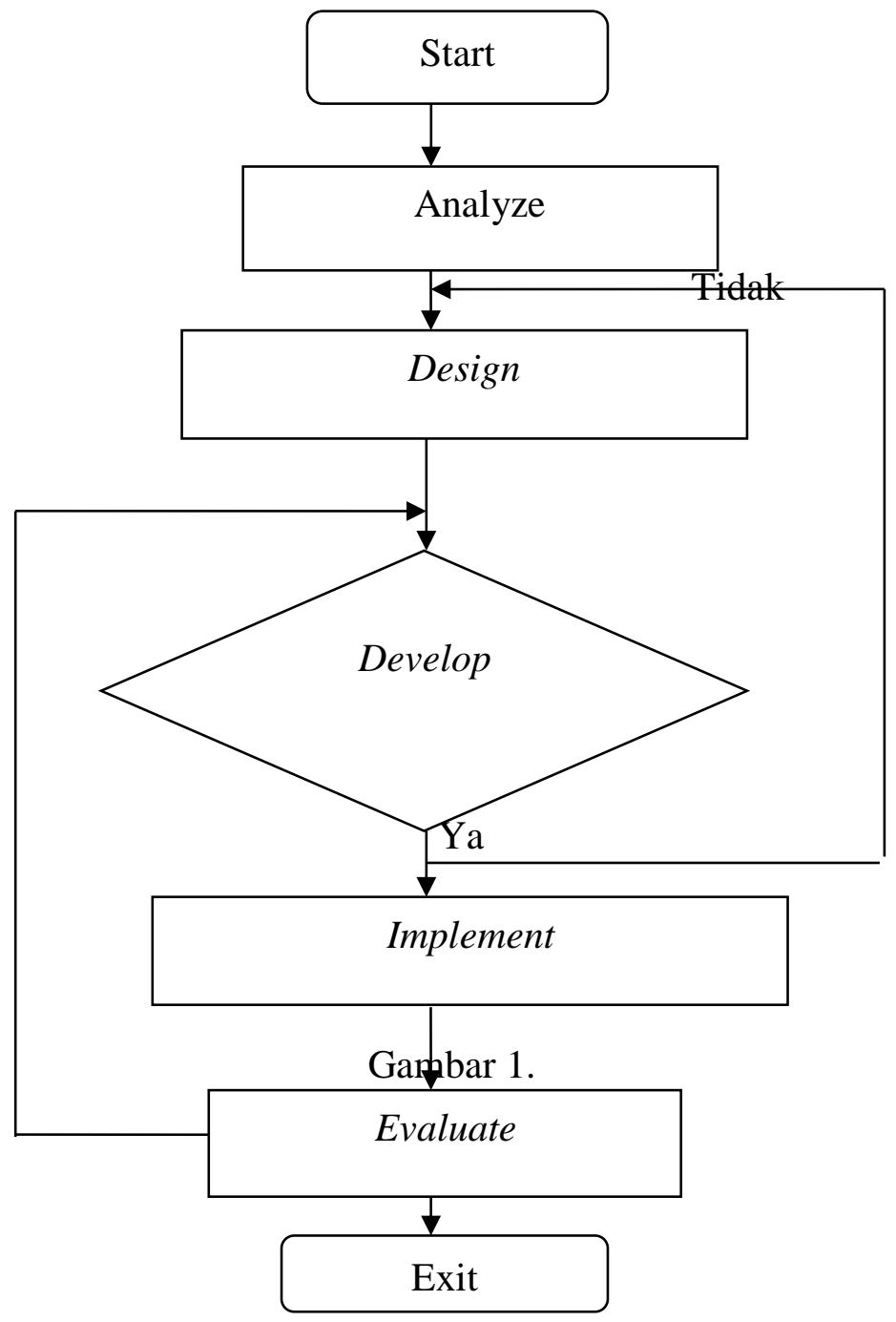

Flowchart Model ADDIE

Adapun penjelasan flowchart diatas adalah sebagai berikut: Analyze, Tahap analisis merupakan suatu proses pendifinisan apa yang akan dipelajari oleh siswa yaitu melakukan analisis kebutuhan, mengidentifikasi masalah, dan melakukan analisis tugas. Oleh karena itu, output yang akan dihasilkan yaitu berupa karateristik siswa, identifikasi kesenjangan, identifikasi kebutuhan dan analisis tugas berdasarkan kebutuhan. Design, merumuskan tujuan pembelajaran, selanjutnya menyusun tes, dimana tes tersebut harus didasarkan pada tujuan pembelajaran yang telah dirumuskan. Develop, Dalam tahap ini kegiatan yang dilakukan adalah membuat video, mengedit video dan menghasilkan produk video pembelajaran. Selanjutnya dilakukan validasi ahli dan guru sebelum diimplementasikan kepada siswa. Implement, tahap ini video pembelajaran untuk digunakan oleh siswa kelas IV pokok bahasan KPK dan FPB. Evaluate, Evaluasi dilakukan untuk menilai kelayakan video pembelajaran oleh ahli, guru dan siswa. Dalam penelitian ini dilakukan beberapa evaluasi yang terdiri dari: 1). evaluasi formatif yaitu evaluasi disaat pengembangan yang melibatkan 2 orang ahli terdiri dari ahli media dan ahli matematika serta 1 orang guru adalah guru kelas, masukan -masukan dari ahli dan guru dilanjutkan tahap revisi video pembelajaran. Tujuan evaluasi untuk melihat tingkat kelayakan video pembelajaran yang dibuat. 2. Evaluasi sumatif yaitu evaluasi akhir yang ditujukan kepada siswa kelas IV sebanyak 27 orang. Tujuannya adalah untuk mengetahui tingkat kepuasan siswa terhadap video pembelajaran matematika pokok bahasan KPK dan FPB.

Untuk mendapatkan data informasi dari ahli dan guru menggunakan instrumen angket dengan penilaian berbentuk skala sikap, instrumen yang digunakan mengacu pada aspek evaluasi media terdiri dari aspek pembelajaran, aspek materi, aspek tampilan serta aspek aksesiblitas (Kyle L. Pech., 1988). Pada penelitian ini hanya menggunakan aspek materi dan aspek tampilan media, skala penilaian yang digunakan adalah skala liker dengan kategori 4: sangat baik, 3, baik, 2, cukup, 1, kurang baik. Data penelitian ini dianalisis menggunakan teknik deskriptif.

\section{HASIL DAN PEMBAHASAN}

Penelitian pengembangan video pembelajaran telah dilakukan dengan kegiatan yang sangat sistematis. Kegiatan diawali dengan observasi dan wawancara terhadap kondisi lapangan, dengan melihat permasalahan yang ada. Dalam hal ini yang menjadi sumber informasi adalah guru kelas, hasil wawancara terbuka dengan guru kelas yaitu hampir $60 \%$ siswa mengalami tingkat kesulitas terhadap pembelajaran yang diberikan secara daring melalui group whatsApp, orang tua siswa banyak meminta 
untuk penjelasan ulang tentang pokok bahasan, siswa merasa jenuh belajar dirumah terus.

Berdasarkan hasil wawancara terbuka dengan guru, peneliti menyimpulkan bahwa perlu ada pembelajaran bervariasi dengan menggunakan video pembelajaran yang menyenangkan sehingga siswa dan orang tua sebagai pendamping dapat menonton video pembelajaran secara berulang, apabila ada pokok bahasan yang kurang dipahami.

Produk Video pembelajaran hasil pengembangan dalam penelitian ini yaitu peneliti membuat video dengan guru, mengedit video dengan menggunakan software KineMaster, dan memproduksi vide pembelajaran. Untuk tahap evaluasi formatif, ada beberapa ahli yang terlibat antara lain ahli media dari jurusan komputer dan ahli materi sarjana pendidikan matematika.

Uji ahli media dilakukan untuk mengetahui tingkat kelayakan media terdiri dari element suara, gambar dan warna, teks, penyaji video. Berdasarkan hasil rekapitulasi penilaian ahli media, dapat dilihat pada gambar dibawah ini.

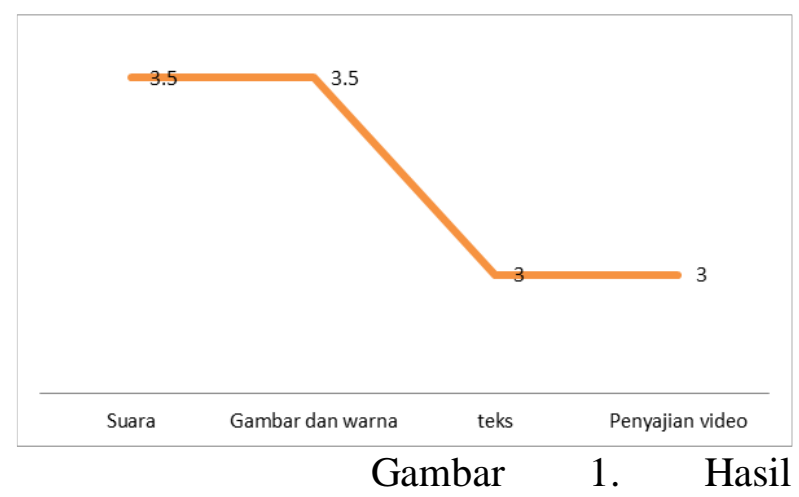

Penialain Ahli Media

Berdasarkan grafik penilaian ahli media terhadap video pembelajaran IPA dengan pokok bahasan kelipatan persekutan terkecil dan faktor persekutuan terbesar bahwa dari segi aspek suara adalah 3,5, aspek gambar dan warna dengan nilai rata-rata 3,5 , aspek teks mendapatkan nilai rata-rata 3 , aspek penyajian video adalah 3. Rata - rata keseluruhan dari penilaian ahli media bahwa media pembelajaran sedangkan nilai rata- rata secara keseluruhan adalah 3,25 artinya video pembelajaran berkategori baik dan layak di lanjutkan pada kelompok sasaran. Adapun masukan dan saran ahli media, sebaiknya membuat video menggunakan kamera yang berkualitas tinggi, sehingga hasil gambarnya bagus dan perlu tim untuk mengambil gambar.

Selanjutnya penilaian oleh ahli materi pembelajaran, dengan kriteria ahli sarjana jurusan matematika. Dalam penilaian ini mencakup kualitas isi, kualitas penyajian dan kualitas Bahasa. Adapun hasilnya dapat dilihat pada gambar dibawah ini.

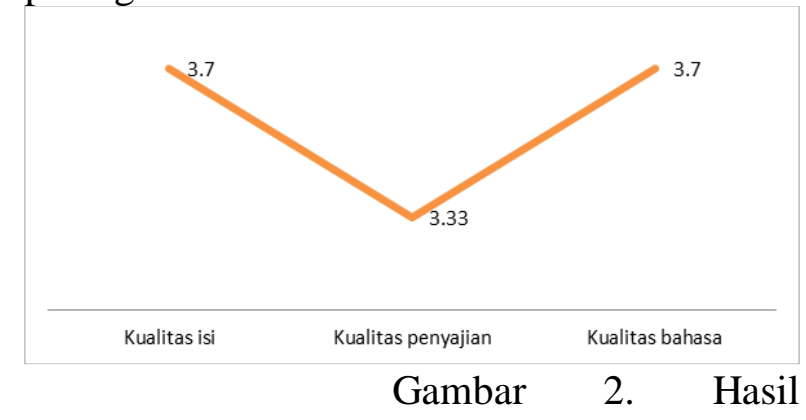

Penilaian Ahli materi

Berdasarkan grafik penilaian ahli materi adalah terdiri dari kualitas isi dengan nilai rata-rata 3,7 , kualitas penyajian nilai ratarata 3,33, dan kualitas bahasa mendapatkan nilai rata- rata 3,7 . Rata-rata kelayakan video pembelajaran dari segi materi adalah berkategori baik. Adapun saran dan masukan dari ahli materi secara keseluruhan sudah baik, perlu ada penambahan pokok bahasan

Uji selanjutnya dilakukan oleh guru. Hasil rekapitulasi penilaian guru dapat dilihat pada gambar dibawah ini

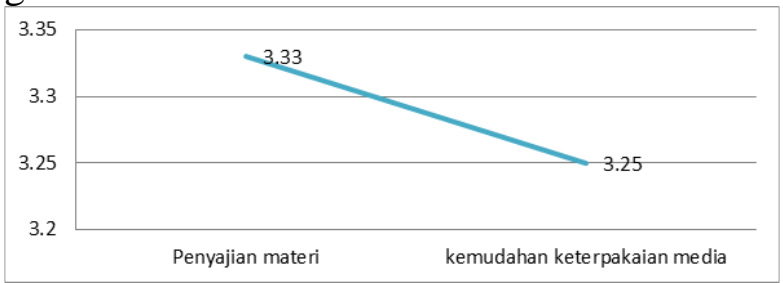

Gambar 3. Hasil penilaian guru

Berdasarkan penilaian guru diatas terhadap video pembelajaran dengan aspek peyajian materi dengan nilai rata-rata 3,33 dan kemudahan keterpakaian media dengan nilai 3,25 , sedangkan keseluruhan hasil penilaian guru adalah rata-rata 3,3 artinya video pembelajaran berkategori baik dan layak digunakan pada kelompok yang lebih besar. Adapun saran dan masukan dari guru secara keseluruhan bahwa perlu ada peningkatan lebih lanjut dari sisi kualitas video.

Setelah dilakukan rangkaian penilaian baik dari ahli media, ahli materi pembelajaran 
dan penilai guru. Hasil dari penilaian media dan ahli materi mengatakan bahwa video pembelajaran berkategori baik, sedangkan hasil penilaian guru mengatakan bahwa video pembelajaran berkategori sangat baik. Peneliti dapat menyimpulkan bahwa hasil ketiga penilaian diatas tentang video pembelajaran layak digunakan pada kelompok yang lebih besar.

Selanjutnya dilakukan uji kelompok besar, untuk hasil dapat dilihat pada gambar dibawah ini.

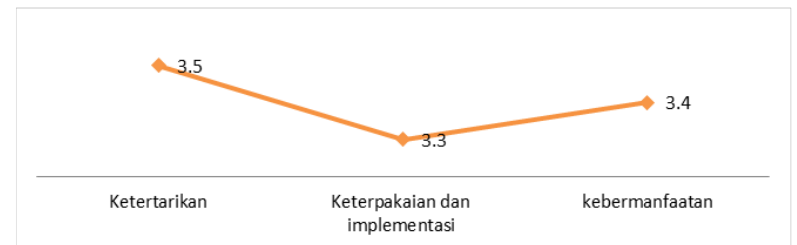

Gambar 4. Hasil uji kelompok besar

Berdasarkan hasil uji kelompok besar adalah aspek ketertarikan siswa dengan nilai rata-rata 3,5, keterpakaian dan implementasi dengan nilai 3,3 dan kebermanfaatan dengan nilai rata-rata 3,4. Secara keseluruhan dengan nilai rerata sebesar 3,34 artinya video pembelajaran berkategori baik.

Pembahasan dalam penelitian ini ialah pengembangan video pembelajaran matematika dengan pokok bahasan KPK dan FPB, melihat tingkat kesulitan yang dihadapi siswa maka peneliti mendorong siswa untuk terus memanfaatkan sumber yang variatif yang menyenangkan agar dapat menunjang kompetensi dan pengetahuan yang dimiliki. Dalam penelitian. Salah satu hal penting dalam video pembelajaran ini,siswa dapat mengulang pembelajaran secara berkala apabila ada halhal yang belum dipahami terhadap mata pelajaran matematika karena video pembelajaran dapat meningkatkan hasil belajar, berdasarkan penelitian yang dilakukan oleh (Purwanti, 2015) dengan judul: pengembangan media video pembelajaran matematika dengan model ASSURE. hasil penelitian tersebut mengatakan bahwa pengembangan media video pembelajaran matematika kompetensi dasar ukuran penyajian data statistik dengan model ASSURE dapat digunakan sebagai media pembelajaran. Selanjutnya hasil penelitian oleh (Ahmad Fadillah, Pengembangan video pembelajaran matematika berbantuan Aplikasi Sparkoll Videoscribe, 2019) dengan judul Pengembangan video pembelajaran matematika berbantuan Aplikasi Sparkoll Videoscribe. Hasil dari penelitian tersebut mengatakan bahwa hasil validasi ahli mendapatkan kriteria layak untuk masingmasing kriteria yaitu $78 \%$ dan $78,7 \%$ dan hasil dari uji coba skala kecil dengan mendapatkan respon positif dan kriteria layak $75,5 \%$.

Adapun pengembangan video pembelajaran matematika pokok bahasan KPK dan FPB yang dikembangkan oleh peneliti diharapkan dapat digunakan oleh siswa untuk memotivasi belajar secara mandiri dirumah selama masa pandemi.

\section{KESIMPULAN}

Adapun kesimpulan dari penelitian ini yaitu penelitian dan pembelajaran telah menghasilkan produk video pembelajaran matematika dengan pokok bahasan kelipatan persekutuan terkecil (KPK) dan faktor persekutuan terbesar (FPB), kemudian setelah dilakukan tahapan - tahapan evaluasi baik evaluasi ahli media, ahli materi serta guru dengan hasil berkategori baik dan bahwa produk video pembelajaran layak digunakan pada kelompok yang lebih besar.

\section{SARAN}

Saran dan masukan dari berbagai pihak diharapkan kedepan bisa melanjutkan kepada uji efektifitas produk yang dibuat serta dapat mengembangkan lagi video pembelajaran pada pokok bahasan yang lain, sehingga siswa lebih leluasa mengulang kembali materi yang disampaikan.

\section{UCAPAN TERIMA KASIH}

Peneliti mengucapkan terima kasih kepada berbagai pihak, terutama Tuhan Yang Maha Esa, kedua orang tua tercinta, Kepala Sekolah dan Guru SDN 06 Tanah Tinggi Jakarta Pusat, istri tercinta dan teman-teman seperjuangan ditanah rantau.

\section{DAFTAR PUSTAKA}

Ahmad Fadillah, W. B. (2019). Pengembangan video pembelajaran matematika berbantuan Aplikasi Sparkoll Videoscribe. Gantang, 177-182. 
https://www.ojs.umrah.ac.id/index.php /gantang/article/view/1369

Kepmendikbud. (t.thn.). nomor 719/P/2020 Tentang Pelaksaanaan kurikulum pada satuan pendidikan dalam kondisi khusus.

Kyle L. Pech., M. H. (1988). "The Design, Development, and Evaluation of instructional software. New York: Macmillan Publishing Company.

Purwanti, B. (2015). Pengembangan media video pembelajaran matematika dengan model ASSURE. kebijakan dan pengembangan pendidikan, 42-47. http://ejournal.umm.ac.id/index.php/jk pp/article/view/2194

Reza Rizki Ali Akbar, K. (2018). Pengembangan video pembelajaran matematika berbantuan media sosial instagram sebagai alternatif pembelajaran. Desimal: Jurnal matematika, $209 \quad-\quad 215$. http://ejournal.radenintan.ac.id/index.p $\mathrm{hp} / \mathrm{desimal} /$ article/view/2343

Robert Maribe Branch., T. A. (2015). Survey of Instructional Design Models. united States Of America: AECT.

Setyosari, P. (2010). Metode Penelitian pendidikan dan Pengembangan. Jakarta: Kencana Prenada Media Group.

Sharon E. Smaldino., D. L. (2011). Instructional technology \& media for learning (Teknologi Pembelajaran dan Media untuk Belajar) (kesembilan ed.). (A. Rahman, Penerj.) jakarta: Kencana Prenada Media Group.

Simarmata, J. d. (2020). Elemen-Elemen Multimedia Teks, Gambar, Video, Animasi untuk Pembelajaran (1 ed.). Medan: Yayasan Kita Menulis.

Sugiyono. (2012). Metode Penelitian Pendidikan Pendekatan Kuantitatif, Kualitatif, dan $R$ \& D. Bandung: Alfabeta.

Titin Suryansyah, S. (2016). Pengembangan Video Pembelajaran Untuk Meningkatkan Motivasi dan Hasil Belajar Kognitif Siswa Kelas IV SD. Prima Edukasia, 209-221. https://journal.uny.ac.id/index.php/jpe/ article/view/8393

Tonni Limbong, E. N. (2020). Multimedia editing video dengan Corel Videostudio X10. Medan: Yayasan Kita Menulis. 